\title{
Effects of addition of malic or citric acids on fermentation quality and chemical characteristics of alfalfa silage
}

\author{
W. C. Ke, ${ }^{\star} \dagger$ W. R. Ding, ${ }^{,} \dagger$ D. M. Xu, ${ }^{*} \dagger$ L. M. Ding, ${ }^{*}$ P. Zhang, ${ }^{*}$ F. D. Li, $\ddagger$ and X. S. Guo ${ }^{*} \dagger^{1}$ \\ *State Key Laboratory of Grassland Agro-Ecosystems, School of Life Sciences, Lanzhou University, Lanzhou 730000, PR China \\ †Probiotics and Biological Feed Research Centre, Lanzhou University, Lanzhou 730000, PR China \\ ‡State Key Laboratory of Grassland Agro-Ecosystems, College of Pastoral Agriculture Science and Technology, Lanzhou University, \\ Lanzhou 730000, PR China
}

\begin{abstract}
We studied the effects on alfalfa preservation and chemical composition of the addition of different levels of malic acid and citric acid at ensiling as well as the utilization efficiency of these 2 organic acids after fermentation. Alfalfa was harvested at early bloom stage. After wilting to a dry matter content of approximately $40 \%$, the alfalfa was chopped into 1 - to 2 -cm pieces for ensiling. Four levels $(0,0.1,0.5$, and $1 \%$ of fresh weight) of malic acid or citric acid were applied to chopped alfalfa at ensiling with 4 replicates for each treatment, and the treated alfalfa forages were ensiled for $60 \mathrm{~d}$ in vacuum-sealed polyethylene bags (dimensions: $200 \mathrm{~mm}$ $\times 300 \mathrm{~mm}$ ) packed with 200 to $230 \mathrm{~g}$ of fresh alfalfa per mini silo and an initial density of $0.534 \mathrm{~g} / \mathrm{cm}^{3}$. The application of malic or citric acids at ensiling for $60 \mathrm{~d}$ led to lower silage $\mathrm{pH}$ than was observed in the control silage ( $0 \%$ of malic or citric acids). Application of the 2 organic acids led to higher lactic acid concentration in alfalfa silage than in the control silage except with the application rate of $1 \%$ of fresh weight. Silages treated with both organic acids had lower nonprotein nitrogen concentrations than the control silages, and the nonprotein nitrogen concentrations in ensiled forages decreased with the increase in malic or citric acid application rates. The application of the 2 organic acid additives led to lower saturated fatty acid proportions and higher polyunsaturated fatty acid proportions in ensiled alfalfa than in the control silage. The amount of malic and citric acids degraded during ensiling of alfalfa was 1.45 and $0.63 \mathrm{~g}$, respectively. At the application rate of $0.5 \%$ of fresh weight, residues of malic acid and citric acid in alfalfa silage were 11.1 and $13.6 \mathrm{~g} / \mathrm{kg}$ of dry matter. These results indicate that including malic or citric acids at the ensiling of alfalfa effectively improved silage fermentation quality, limited proteolysis,
\end{abstract}

Received March 15, 2017.

Accepted July 30, 2017.

${ }^{1}$ Corresponding author: guoxsh07@lzu.edu.cn improved fatty acid composition of the ensiled forage, and could provide animals with additional feed additives proven to promote animal performance. However, when the application rate of both organic acids reached $1 \%$, the concentration of lactic acid in silages decreased notably. Additionally, 0.5 and $1 \%$ application rates also increased the yeast count in ensiled alfalfa.

Key words: malic acid, citric acid, alfalfa silage, organic acid

\section{INTRODUCTION}

Extensive research over recent years has explored the potential of using organic acids (e.g., fumaric, malic, citric, and succinic acids) as alternatives to feed antibiotics to improve performance and feed efficiency. As a key intermediate in the citric acid cycle of biological tissues and in the succinate-propionate pathway of ruminal bacteria (Castillo et al., 2004), malic acid has been introduced as a feed additive for ruminants because of its numerous beneficial effects. Many in vitro studies have shown that malic acid could stimulate rumen fermentation, increase rumen $\mathrm{pH}$ (Martin and Streeter, 1995; Carro and Ranilla, 2003), improve microbial N production and microbial efficiency (Sniffen et al., 2006), decrease methane production (Carro and Ranilla, 2003), and increase feed digestibility (Carro et al., 1999). Feeding trials also confirmed that malic acid had a positive effect on increasing milk production in dairy cows (Sniffen et al., 2006; Devant et al., 2007; Wang et al., 2009b) and improving beef cattle performance (Martin et al., 1999; Castillo et al., 2007). Citric acid is another essential intermediate in the citric acid cycle, which has a similar function in stimulating rumen fermentation and improving animal performance (Packett and Butcher, 1963; Sun et al., 2008; Wang et al., 2009a).

To date, little information is available on the application of malic acid or citric acid in ensiled forage, and whether these organic acids have positive effects on promoting the fermentation quality of ensiled alfalfa 
is not clear. Even so, the existing literature shows that malic acid or citric acid could accelerate the growth of lactic acid bacteria (LAB; Branen and Keenan, 1970; Salou et al., 1991; Passos et al., 2003). Therefore, it is plausible that the application of malic acid or citric acid could possibly improve the fermentation of ensiled forage and consequently decrease proteolysis by promoting $\mathrm{pH}$ decline. Based on the positive effects of the abovementioned organic acids in stimulating microbial fermentation and their use as feed additives for improving animal performance, we propose that the application of these organic acids at ensiling may not only improve fermentation quality and nutritive value of ensiled forage but could also indirectly provide animals with feed additives after ingestion of organic acid-treated silages. However, whether these 2 acids have different effects on fermentation of ensiled forage is not clear. It is also necessary to clarify the degradation of the added organic acids after fermentation to see whether the residues in silages are enough to meet the amount of organic acids for improving animal performance as suggested by previous studies. In addition, the fatty acid (FA) composition in ensiled forages has been of interest. It has been reported that a high intake of PUFA could increase the concentration of PUFA in ruminant products (Wood and Enser, 1997; Kalač and Samková, 2010) and consequently be beneficial to human health (Simopoulos, 2001). It was reported that ensiling led to lower PUFA but higher SFA compared with fresh forage due to lipolysis and biohydrogenation (Alves et al., 2011). Because malic and citric acids are well-known antioxidants, they might inhibit the lipolysis caused by lipoxygenases during ensiling. Thus, the objectives of this study were to investigate the effects of different levels of malic or citric acids on fermentation quality, proteolysis, and lipolysis of alfalfa silage and to evaluate the utilization efficiency of these 2 organic acids in ensiled alfalfa after fermentation.

\section{MATERIALS AND METHODS}

\section{Experimental Treatments and Mini Silo Preparation}

Alfalfa (Medicago sativa L.) was mowed in the late bud to early bloom stage and wilted to a DM content of approximately $400 \mathrm{~g} / \mathrm{kg}$ of fresh weight (FW). A total of $8 \mathrm{~kg}$ of the wilted forage was then chopped into 1- to 2 -cm pieces using a paper cutter within $40 \mathrm{~min}$. The chopped forage was then treated with malic acid or citric acid at application rates of $0,0.1,0.5$, and $1 \%$ of $\mathrm{FW}$. To apply the organic acids to the chopped alfalfa forage, malic acid or citric acid was dissolved in $12 \mathrm{~mL}$ of distilled water and mixed thoroughly with the forages after uniform spraying onto the piles prepared for each treatment. For the untreated forage, the same amount of distilled water alone was applied. The $\mathrm{pH}$ values in alfalfa treated with malic acid at 0.1 , 0.5 , and $1 \%$ at ensiling were $6.02 \pm 0.01,5.21 \pm 0.02$, and $4.95 \pm 0.06$, respectively, and the $\mathrm{pH}$ values in alfalfa treated with citric acid at $0.1,0.5$, and $1 \%$ at ensiling were $6.0 \pm 0.02,5.3 \pm 0.01$, and $4.79 \pm 0.02$, respectively. To accurately trace the degradation of the organic acids before and after fermentation, laboratory vacuum packed mini silos were used (Johnson et al., 2005; Hoedtke and Zeyner, 2011). All the treated forages were packed into polyethylene plastic bags with initial density of $0.534 \mathrm{~g} / \mathrm{cm}^{3}$ (dimensions: $200 \mathrm{~mm} \times$ $300 \mathrm{~mm}$; Embossed Food saver bag; Taizou Wenbwu Soft-Packing Color-Printing Co. Ltd., Zhejiang, China) and vacuum sealed tightly. Each polyethylene bag was packed with 200 to $230 \mathrm{~g}$ of wilted forage, and there were 4 replicates for each treatment. The silos were then stored at an ambient temperature of $25 \pm 2^{\circ} \mathrm{C}$ for $60 \mathrm{~d}$.

\section{Chemical and FA Analyses}

After $60 \mathrm{~d}$ of ensiling, the bags were opened and a portion of silage immediately was frozen $\left(-20^{\circ} \mathrm{C}\right)$ for further analysis. Initial fresh forage samples were taken before samples were ensiled. A 20-g FW sample from each bag was placed in a juice extractor (BA-828, Mannengda Plasthetics Co. Ltd., Guangzhou, China), diluted with $180 \mathrm{~mL}$ of distilled water, squeezed for $30 \mathrm{~s}$ at a high speed, and filtered through 4 layers of medical gauze. The filtrate was divided into 2 parts. The $\mathrm{pH}$ was measured immediately; then, one part of the filtrate was acidulated with $7.14 \mathrm{M} \mathrm{H}_{2} \mathrm{SO}_{4}$ and filtered with a $0.45-\mu \mathrm{m}$ dialyzer. Lactic acid, acetic acid, propionic acid, and butyric acid were analyzed by HPLC (Shodex KC-811 column; Shimadzu, Kyoto, Japan; oven temperature: $50^{\circ} \mathrm{C}$; flow rate: $1 \mathrm{~mL} / \mathrm{min}$; SPD-10Avp, Shimadzu: $210 \mathrm{~nm}$ ) as described previously (Ding et al., 2013). A total of $1 \mathrm{~mL}$ of 250 $\mathrm{g} / \mathrm{L}$ (wt/vol) trichloroacetic acid was added to $4 \mathrm{~mL}$ of the second part of the filtrate from each bag. This solution was held overnight at $4^{\circ} \mathrm{C}$ to precipitate the protein and was centrifuged at 18,000 $\times g$ for $15 \mathrm{~min}$ at $4^{\circ} \mathrm{C}$. Next, the supernatant fluid was analyzed for ammonia nitrogen $\left(\mathbf{N H}_{3}-\mathbf{N}\right)$ and AA nitrogen (AAN) according to Broderick and Kang (1980) and for water-soluble carbohydrates (WSC) using the method of Thomas (1977). The NPN content of forage samples was analyzed after precipitating protein by using trichloroacetic acid as described by Licitra et al. (1996). Enumeration of LAB, yeasts, and molds in fresh alfalfa 
and ensiled forage was performed according to methods described by Reich and Kung (2010). Briefly, samples (10 g) were homogenized in $100 \mathrm{~mL}$ of sterile Ringer's solution (Oxoid BR52, Basingstoke, UK) for $1 \mathrm{~min}$ and serially diluted (10-fold). The number of LAB was enumerated on spread plates using Rogosa agar (Oxoid CM627, Oxoid) and incubated at $30^{\circ} \mathrm{C}$ for 48 to 72 $\mathrm{h}$. Yeasts and molds were determined by pour plating serial 10-fold dilutions of water extracts on malt extract agar (Oxoid CM0059) that had been acidified with lactic acid (concentration of $850 \mathrm{~g} / \mathrm{kg}$ added at $50 \mathrm{~g} / \mathrm{kg}$, $\mathrm{vol} / \mathrm{vol}$ ). Plates were incubated at $32^{\circ} \mathrm{C}$ for 48 to $72 \mathrm{~h}$. Colonies were counted from plates where appropriate dilutions yielded 30 to 300 colonies.

The DM content of the fresh forage and the remaining ensiled forage from each silo were measured by drying the samples in a forced-air oven at $65^{\circ} \mathrm{C}$ for $72 \mathrm{~h}$. Dried samples were ground with a mill (1-mm screen). Ground samples were analyzed for Kjeldahl N (AOAC, 1990). Crude protein was calculated as Kjeldahl N $\times$ 6.25. The content of NDF assayed with heat-stable amylase (aNDF) and ADF was determined according to the methods of Van Soest et al. (1991) using an Ankom 200 fiber analyzer (Ankom Technology, Fairport, NY). During the analysis procedure, heat-stable $\alpha$-amylase and sodium sulfite were added. The aNDF and ADF were expressed in terms of residual ash.

To analyze FA in the forages, samples were lyophilized using a freeze dryer (Labconco, Kansas City, MO) and then milled through a 1-mm screen. Fatty acids of samples (0.6 g each) were extracted using methylbenzene and methyl esterified according to the method of Sukhija and Palmquist (1988) except that $1 \mathrm{~mL}$ of an internal standard [1 mg/L of methyl 10-heptadecenoate (C17:0)] dissolved in chloroform was added. Extracted lipids were then dissolved in $5 \mathrm{~mL}$ of hexane, and 0.5 $\mathrm{mL}$ of Na-methylate $(0.5 M)$ was added. The mixture was vortexed and allowed to react for 5 min. Following this, $1 \mathrm{~g}$ of $\mathrm{NaHSO}_{4}$ was added and, after vortexing for a further $2 \mathrm{~min}$, the samples were centrifuged at 1,400 $\times g$ for $5 \mathrm{~min}$ at $4^{\circ} \mathrm{C}$. The upper liquid layer was used for the determination of FAME by GC with attached MS (model 6890N-5975C, Agilent Technologies, Santa Clara, CA) fitted with a fused-silica capillary column $(30 \mathrm{~m} \times 0.25 \mathrm{~mm} \times 0.50 \mu \mathrm{m}$; DB-FFAP, Agilent $)$ as described previously (Ding et al., 2013).

\section{Malic and Citric Acid Analyses}

Malic acid and citric acid in fresh and ensiled forages were extracted from the ground samples by the method of Callaway et al. (1997). Briefly, ground samples (0.8 g) were mixed with $20 \mathrm{~mL}$ of distilled water in a $100-$
$\mathrm{mL}$ screw bottle and then boiled in a $100^{\circ} \mathrm{C}$ water bath for $30 \mathrm{~min}$. After it was stirred thoroughly with a glass stirring rod, the slurry was filtered through a Buchner funnel fixed with a filter paper. An additional $20 \mathrm{~mL}$ of distilled water was used to rinse excess organic acid and residue from the screw bottle. The filtrate was collected and then centrifuged for $10 \mathrm{~min}$ at $10,000 \times g$ at room temperature. After filtering through a $0.22-\mu \mathrm{m}$ membrane, the filtrate was used for the measurement of malic acid and citric acid by using HPLC (KC-811 column, Shodex; oven temperature: $50^{\circ} \mathrm{C}$; SPD: 210 $\mathrm{nm})$. Samples were eluted from the column with $6 \mathrm{mM}$ $\mathrm{H}_{4} \mathrm{ClO}_{4}$ at a flow rate of $0.5 \mathrm{~mL} / \mathrm{min}$.

\section{Statistical Analysis}

Data were analyzed using the GLM procedure of SAS (SAS Institute Inc., Cary, NC) according to the model for a $2 \times 4$ factorial treatment design:

$$
\mathrm{Y}_{\mathrm{ijk}}=\mu+\alpha_{\mathrm{i}}+\mathrm{b}_{\mathrm{j}}+(\alpha \times b)_{\mathrm{ij}}+\mathrm{e}_{\mathrm{ijk}},
$$

where $Y_{\mathrm{ijk}}$ represents the chemical composition and fermentative characteristics of the ensiled forages, $\mu$ is the overall mean, $\alpha_{i}$ is the effect of organic acid treatments $\mathrm{i}(\mathrm{i}=1,2), \mathrm{b}_{\mathrm{j}}$ is the effect of application rates $\mathrm{j}(\mathrm{j}=1$, $2,3$, or 4$),(\alpha \times b)_{i j}$ is the effect of interaction between organic acid treatments and application rates, and $e_{\mathrm{ijk}}$ is the error term. Polynomial contrast was used to examine effects of the unequally spaced application rate (by first generating the coefficients using PROC IML of SAS) as well as the organic acid type $\times$ application rate interactions. Comparisons between organic acid types within each application rate of organic acid were made using $t$-tests when at least one of the contrasts of organic acid type $\times$ application rate was significant. Differences were considered significant at $P<0.05$ and a trend at $P<0.10$.

\section{RESULTS}

\section{Chemical Composition and Epiphytic Microflora of Forage Before Ensiling}

The chemical composition and epiphytic microflora of the freshly chopped alfalfa are shown in Table 1. Before ensiling, fresh alfalfa was wilted to a DM content of $432 \mathrm{~g} / \mathrm{kg}$, and the $\mathrm{pH}$ value was 6.21 . The counts of epiphytic microbes in fresh alfalfa such as LAB, yeasts, and molds were $6.37,6.65$, and $6.51 \log _{10} \mathrm{cfu} / \mathrm{g}$, respectively. Only small amounts of malic acid $(17.11 \mathrm{~g} / \mathrm{kg}$ of $\mathrm{DM})$ and citric acid $(9.16 \mathrm{~g} / \mathrm{kg}$ of $\mathrm{DM})$ were detected in the untreated alfalfa at ensiling. 
Table 1. Chemical composition and epiphytic microflora of fresh alfalfa before ensiling (mean $\pm \mathrm{SD}$ )

\begin{tabular}{lc}
\hline Item & Value \\
\hline $\mathrm{DM}, \mathrm{g} / \mathrm{kg}$ & $432 \pm 8.12$ \\
$\mathrm{pH}$ & $6.21 \pm 0.06$ \\
$\mathrm{CP}, \mathrm{g} / \mathrm{kg}$ & $200 \pm 2.34$ \\
$\mathrm{aNDF}, \mathrm{g} / \mathrm{kg}$ of DM & $384 \pm 8.0$ \\
$\mathrm{ADF}, \mathrm{g} / \mathrm{kg}$ of DM & $287 \pm 7.4$ \\
$\mathrm{WSC}, \mathrm{g} / \mathrm{kg}$ of DM & $60.7 \pm 0.86$ \\
$\mathrm{Lactic}$ acid bacteria, $\log _{10} \mathrm{cfu} / \mathrm{g}$ of $\mathrm{FM}^{3}$ & $6.37 \pm 0.02$ \\
Yeasts, $\log _{10} \mathrm{cfu} / \mathrm{g}$ of FM & $6.65 \pm 0.04$ \\
Molds, $\log _{10} \mathrm{cfu} / \mathrm{g}$ of $\mathrm{FM}$ & $6.51 \pm 0.02$ \\
Malic acid, g/kg of DM & $17.1 \pm 0.13$ \\
Citric acid, g/kg of DM & $9.2 \pm 0.03$ \\
\hline
\end{tabular}

${ }^{1}$ aNDF $=$ NDF assayed with a heat-stable amylase and expressed inclusive of residual ash.

${ }^{2} \mathrm{WSC}=$ water-soluble carbohydrate.

${ }^{3} \mathrm{FM}=$ fresh matter.

\section{Fermentation Characteristics of Alfalfa Silages Ensiled for $60 \mathrm{~d}$}

The application of malic or citric acids at ensiling of alfalfa led to lower silage $\mathrm{pH}(P<0.05$; Table 2$)$ compared with the control silage. Lower silage $\mathrm{pH}$ on average was observed in citric acid-treated silages than in malic acid-treated silages, but the difference was extremely small and not of practical significance (4.81 vs. $4.85 ; P<0.01)$. The $\mathrm{pH}$ decreased and the lactic acid concentration increased linearly and quadratically with increases in the application rate of either acid $(P<0.01)$. Lactic acid concentration was greater in malic acid-treated silages when the application rates were 0.1 or $0.5 \%$ but was greater in citric acid-treated silages when the application rate reached $1 \%$ (linear interaction; $P<0.05)$. Application of these 2 organic acids at the low level of $0.1 \%$ led to higher lactic acid concentration and lower yeast amounts compared with the control silage $(P<0.05)$, but when the application rates reached 0.5 or $1 \%$, higher yeast amounts in alfalfa silage were observed. The yeasts increased linearly $(P$ $<0.001$ ) with the increases in application rate (from 0.1 to $1 \%$ ). Treatments with $0.1 \%$ malic acid had a higher yeast population than did those with $0.1 \%$ citric acid, but lower yeast populations were observed in 0.5 or $1 \%$ malic acid-treated silages compared with 0.5 or $1 \%$ citric acid-treated silages (linear interaction; $P<$ 0.001). Both malic and citric acids at all application rates decreased mold populations in ensiled forage $(P$ $<0.05)$.

\section{Chemical Composition of Alfalfa Silages Ensiled for $60 \mathrm{~d}$}

The chemical composition of alfalfa silages ensiled for $60 \mathrm{~d}$ is shown in Table 3. The increased application rates of organic acid linearly increased silage DM content $(P<0.001)$. The DM contents were greater in citric acid-treated silages when the application rate was 0.1 or $0.5 \%$ but were greater in malic acid-treated silages when the application rate was $1 \%$ (linear and quadratic interactions; $P<0.05)$. On average, the concentration of WSC was higher in silages treated with malic acid than in those treated with citric acid (15.45 vs. $10.64 \mathrm{~g} / \mathrm{kg}$ of DM; $P<0.001$ ), and with the increase of organic acid application rates (from 0.1 to $1 \%$ ), the WSC concentration in ensiled forages increased accordingly. The NPN concentration decreased linearly $(P<0.01)$ with the increase of citric acid application rates, and the effect of malic acid was curvilinear with

Table 2. Fermentation characteristics of alfalfa silages ensiled for $60 \mathrm{~d}$

\begin{tabular}{|c|c|c|c|c|c|c|c|c|c|c|c|}
\hline Item & Acid type $^{1}$ & \multicolumn{4}{|c|}{ Application rate $(\%)$} & SEM & \multicolumn{5}{|c|}{$P$-value ${ }^{2}$} \\
\hline $\mathrm{pH}$ & Malic acid & 5.19 & 4.85 & 4.58 & 4.79 & 0.006 & 0.01 & $<0.001$ & $<0.001$ & 0.015 & 0.005 \\
\hline \multirow[t]{2}{*}{ Lactic acid, $\mathrm{g} / \mathrm{kg}$ of DM } & Malic acid & 67.0 & 92.2 & 81.1 & 37.1 & 1.75 & 0.309 & $<0.001$ & $<0.001$ & 0.026 & 0.156 \\
\hline & Citric acid & 67.0 & 88.3 & 78.9 & 58.1 & & & & & & \\
\hline Acetic acid, $\mathrm{g} / \mathrm{kg}$ of $\mathrm{DM}$ & Malic acid & 13.2 & 10.4 & 10.8 & 12.2 & 0.39 & 0.244 & 0.048 & 0.006 & 0.046 & 0.244 \\
\hline $\begin{array}{l}\text { Lactic acid bacteria, } \\
\log _{10} \mathrm{cfu} / \mathrm{g} \text { of } \mathrm{FM}^{3}\end{array}$ & Citric acid & 7.44 & 7.39 & 6.84 & 6.85 & & & & & & \\
\hline \multirow[t]{2}{*}{ Yeasts, $\log _{10} \mathrm{cfu} / \mathrm{g}$ of FM } & Malic acid & 4.18 & 3.60 & 4.43 & 4.42 & 0.022 & $<0.001$ & $<0.001$ & $<0.001$ & $<0.001$ & 0.001 \\
\hline & Citric acid & 4.18 & 3.16 & 5.19 & 5.10 & & & & & & \\
\hline \multirow[t]{2}{*}{ Molds, $\log _{10} \mathrm{cfu} / \mathrm{g}$ of FM } & Malic acid & 4.40 & 3.16 & 3.16 & 3.16 & 0.049 & 0.094 & $<0.001$ & $<0.001$ & 0.439 & 0.126 \\
\hline & Citric acid & 4.40 & 3.09 & 2.69 & 3.00 & & & & & & \\
\hline
\end{tabular}

${ }^{1}$ Organic acid-treated alfalfa silages.

${ }^{2} \mathrm{~A}=$ acid type; $\mathrm{AR}-\mathrm{L}=$ linear effect of application rate; $\mathrm{AR}-\mathrm{Q}=$ quadratic effect of application rate; $\mathrm{AR}-\mathrm{L} \times \mathrm{A}=$ interaction of linear application rate effect with acid type; $\mathrm{AR}-\mathrm{Q} \times \mathrm{A}=$ interaction of quadratic application rate effect with acid type.

${ }^{3} \mathrm{FM}=$ fresh matter. 
Table 3. Chemical composition of alfalfa silages ensiled for $60 \mathrm{~d}$

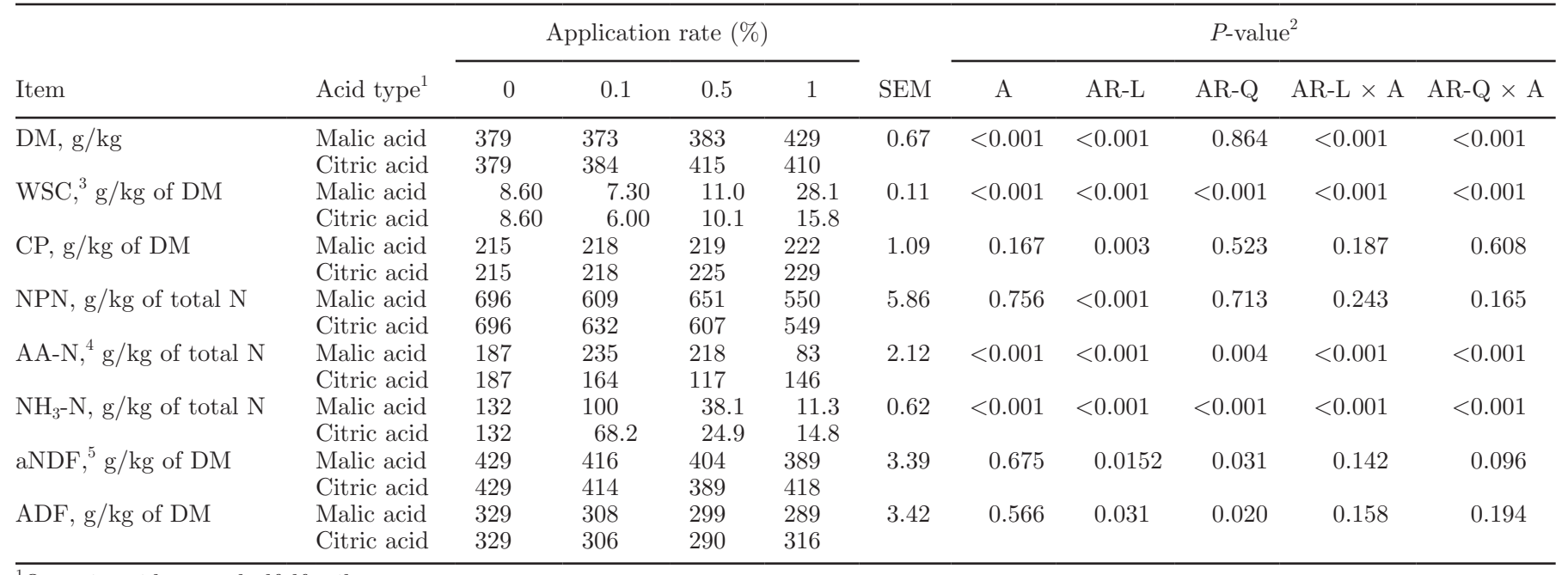

${ }^{1}$ Organic acid-treated alfalfa silages.

${ }^{2} \mathrm{~A}=$ acid type; $\mathrm{AR}-\mathrm{L}=$ linear effect of application rate; $\mathrm{AR}-\mathrm{Q}=$ quadratic effect of application rate; $\mathrm{AR}-\mathrm{L} \times \mathrm{A}=$ interaction of linear application rate effect with acid type; $\mathrm{AR}-\mathrm{Q} \times \mathrm{A}=$ interaction of quadratic application rate effect with acid type.

${ }^{3} \mathrm{WSC}=$ water-soluble carbohydrate.

${ }^{4} \mathrm{AA}-\mathrm{N}=$ free AA nitrogen.

${ }^{5} \mathrm{aNDF}=\mathrm{NDF}$ assayed with a heat-stable amylase and expressed inclusive of residual ash.

an increase in NPN in the $0.5 \%$ malic acid treatment. Additionally, silages treated with either of the organic acids had lower NPN concentrations than did the control silages $(P<0.05)$. An interaction between organic acid type and application rate was observed in AA-N and $\mathrm{NH}_{3}-\mathrm{N}$. The AA-N and $\mathrm{NH}_{3}-\mathrm{N}$ were higher in malic acid-treated silages under the application rates of 0.1 or $0.5 \%$ but higher in citric acid-treated silages under the highest application rate of $1 \%$ (linear and quadratic interactions; $P<0.05$ ). There were effects of organic acid type and their application rates on the concentration of $\mathrm{NH}_{3}-\mathrm{N}$ in ensiled forages, and lower $\mathrm{NH}_{3}-\mathrm{N}$ concentrations on average were observed in citric acidtreated silages than in the malic acid-treated silages (35.9 vs. $49.9 \mathrm{~g} / \mathrm{kg}$ of total $\mathrm{N} ; P<0.05)$. Moreover, application of malic or citric acids at ensiling led to lower $\mathrm{NH}_{3}-\mathrm{N}$ concentrations than those observed in the control silages $(P<0.05)$.

\section{FA Composition of Fresh Alfalfa and Alfalfa Silages Ensiled for $60 \mathrm{~d}$}

On average, total FA in citric acid-treated silages was greater than that in malic acid-treated silages (22.05 vs. $19.18 \mathrm{~g} / \mathrm{kg}$ of DM; $P<0.05$; Table 4$)$. On average, the application of the 2 organic acid additives led to lower SFA proportions and higher PUFA proportions in ensiled alfalfa $(P<0.05)$ than in the control silages. In addition, citric acid-treated silage had a lower proportion of SFA and a greater proportion of PUFA in total FA at the respective application rates than malic acid-treated silage $(P<0.05)$. There were organic acid type $\times$ application rate linear interactions on SFA and PUFA $(P<0.001)$. The SFA decreased and PUFA increased linearly and quadratically $(P<0.01)$ in silage with the increased application rates of the organic acids. As expected, a higher proportion of C16:0 in total FA was observed after alfalfa was ensiled for 60 $\mathrm{d}$ than in fresh alfalfa. Application of these acids led to a lower proportion of C16:0 than in the control silage, and C16:0 was higher in malic acid-treated silages than in citric acid-treated silages under an application rate of $0.1 \%(P<0.05)$. Although there was no difference between the 2 additives in the proportion of C16:0 in total FA, applying malic acid or citric acid at ensiling led to a markedly higher proportion of cis-9, cis12,cis-15 C18:3 in total FA of ensiled forage than in the control silage $(P<0.05)$, and the FA proportion of cis-9,cis-12,cis-15 C18:3 in the silage treated with citric acid was greater than that in the silage treated with malic acid $(P<0.05)$. There was also an organic acid type $\times$ application rate interaction for the proportion of cis-9,cis-12,cis-15 C18:3. The increased application rates of citric acid resulted in increased proportion of cis-9,cis-12,cis-15 C18:3 in silage, but no differences in the proportion were observed among the silages treated with the 3 application rates of malic acid. 
Table 4. Total fatty acid (FA) content (mg/g of DM) and the major FA composition ( $\mathrm{g} / 100 \mathrm{~g}$ of total FA) of fresh alfalfa and alfalfa silages ensiled for $60 \mathrm{~d}$

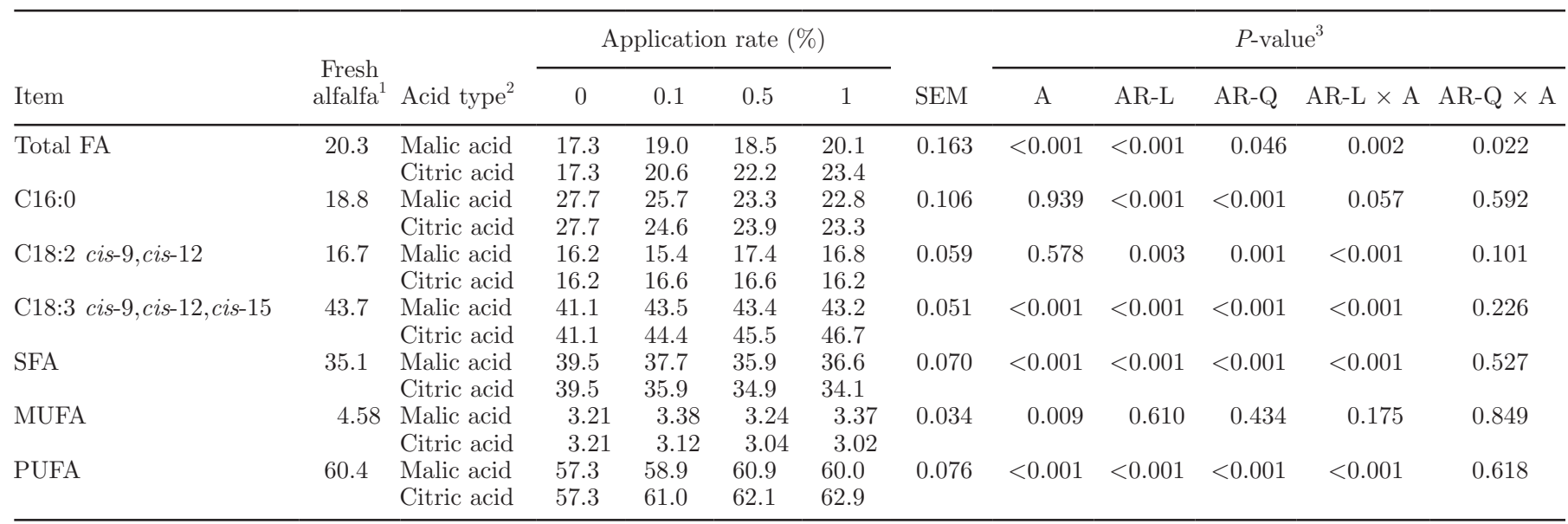

\section{${ }^{1}$ Alfalfa before ensiling. \\ ${ }^{2}$ Organic acid-treated alfalfa silages. \\ Degradation and Residue of Malic Acid and Citric Acid in Alfalfa Silages Ensiled for $60 \mathrm{~d}$}

${ }^{3} \mathrm{~A}=$ acid type; AR-L = linear effect of application rate; $\mathrm{AR}-\mathrm{Q}=$ quadratic effect of application rate; $\mathrm{AR}-\mathrm{L} \times \mathrm{A}=$ interaction of linear application rate effect with acid type; $\mathrm{AR}-\mathrm{Q} \times \mathrm{A}=$ interaction of quadratic application rate effect with acid type.

The residue and utilization efficiency of malic and citric acids in alfalfa silages are shown in Table 5. After ensiling, concentrations of malic acid and citric acid decreased from 17.9 and $9.2 \mathrm{~g} / \mathrm{kg}$ of DM to 2.7 and $4.23 \mathrm{~g} /$ $\mathrm{kg}$ of DM, respectively. As expected, on average higher residues of malic acid were found in silages treated with malic acid than in those treated with citric acid (12.3 vs. $8.4 \mathrm{~g} / \mathrm{kg}$ of DM; $P<0.05)$. The degraded amounts of malic acid in ensiled forage did not increase with the increase of malic acid application rates from 0.1 to $1 \%$ of $\mathrm{FW}$, but the increased application rates of citric acid decreased the amount of degraded malic acid in ensiled forage $(P<0.05)$. The highest degradation rate of malic acid was observed in silages treated with $0.1 \%$ of malic acid. The average degradation rates of malic acid in silages treated with malic and citric acids were 62 and $55 \mathrm{~g} / 100 \mathrm{~g}$, respectively. Small amounts of citric acid were degraded in silages treated with 0.1 and $0.5 \%$ of malic acid, and an even higher amount of citric acid $(11.6 \mathrm{~g} / \mathrm{kg}$ of DM) was detected in silage treated with $1 \%$ of malic acid compared with fresh forage $(9.2 \mathrm{~g} / \mathrm{kg}$ of DM). The amount of degraded citric acid decreased with the increased application rates of malic acid $(P<$ $0.05)$, whereas the increased application rates of citric acid did not affect the amount of citric acid degraded in silage. The average degradation rates of citric acid in silages treated with malic and citric acids were 10.9 and $37.7 \mathrm{~g} / 100 \mathrm{~g}$, respectively.

\section{DISCUSSION}

It is well known that it is difficult to generate good silage using alfalfa because of its high buffer capacity and low WSC concentration (Owens et al., 1999). Therefore, inoculants and organic acids such as formic acid, propionic acid, and benzoic acid are commonly used to promote a rapid decline of silage $\mathrm{pH}$ and to improve the fermentation quality of ensiled forage (Mills and Kung, 2002; Tyrolova and Vyborna, 2008; Li et al., 2016). However, the corrosive effect of these organic acids on machinery during application is a problem in practice despite buffered organic acids currently being used. Malic and citric acids are widely used in the food industry because of their safety, in addition to many other uses. In the present study, the lower $\mathrm{pH}$, greater lactic acid, and lower acetic acid concentrations in silages treated with malic and citric acids (at application rates of 0.1 or $0.5 \%$ of $\mathrm{FW}$ ) indicate that including malic or citric acids at ensiling could improve or alter the fermentation process of the ensiled alfalfa. These acids were also reported to stimulate in vitro mixed ruminal microorganism fermentation (Martin and Streeter, 1995; Carro and Ranilla, 2003; Wang et al., 2009a). Nevertheless, when the application level of these 2 acids reached $1 \%$ of $\mathrm{FW}$, remarkable declines in the lactic acid concentration and the number of LAB were observed, which suggests that the growth and fermentation of LAB were inhibited by the high concentration of malic or citric acids in ensiled forage. These results are probably attributable to the low $\mathrm{pH}$ 
Table 5. Residue and degradation of malic acid and citric acid in alfalfa silages ensiled for $60 \mathrm{~d}$

\begin{tabular}{|c|c|c|c|c|c|c|c|c|c|c|c|}
\hline Item & Acid type $^{1}$ & \multicolumn{4}{|c|}{ Application $\operatorname{rate}^{2}(\%)$} & SEM & \multicolumn{5}{|c|}{$P$-value ${ }^{3}$} \\
\hline $\begin{array}{l}\text { Residue of malic acid, } \mathrm{g} / \mathrm{kg} \\
\text { of DM }\end{array}$ & $\begin{array}{l}\text { Malic acid } \\
\text { Citric acid }\end{array}$ & $\begin{array}{l}2.70 \\
2.70\end{array}$ & $\begin{array}{l}2.60 \\
3.47\end{array}$ & $\begin{array}{c}11.1 \\
7.88\end{array}$ & $\begin{array}{l}23.3 \\
13.8\end{array}$ & 0.185 & $<0.001$ & $<0.001$ & 0.174 & $<0.001$ & $<0.001$ \\
\hline $\begin{array}{l}\text { Amount of malic acid } \\
\text { degraded, }{ }^{4} \mathrm{~g}\end{array}$ & $\begin{array}{l}\text { Malic acid } \\
\text { Citric acid }\end{array}$ & $\begin{array}{l}1.33 \\
1.33\end{array}$ & $\begin{array}{l}1.42 \\
1.23\end{array}$ & $\begin{array}{l}1.60 \\
0.91\end{array}$ & $\begin{array}{l}1.32 \\
0.38\end{array}$ & 0.011 & $<0.001$ & $<0.001$ & $<0.001$ & $<0.001$ & $<0.001$ \\
\hline $\begin{array}{l}\text { Degradation rate of malic acid, } \\
\mathrm{g} / 100 \mathrm{~g}\end{array}$ & $\begin{array}{l}\text { Malic acid } \\
\text { Citric acid }\end{array}$ & $\begin{array}{l}86.7 \\
86.7\end{array}$ & $\begin{array}{l}88.8 \\
82.7\end{array}$ & $\begin{array}{l}66.9 \\
56.8\end{array}$ & $\begin{array}{l}39.8 \\
25.6\end{array}$ & 0.429 & $<0.001$ & $<0.001$ & 0.174 & $<0.001$ & 0.032 \\
\hline $\begin{array}{l}\text { Amount of citric acid } \\
\text { degraded, }{ }^{5} \mathrm{~g}\end{array}$ & $\begin{array}{l}\text { Malic acid } \\
\text { Citric acid }\end{array}$ & $\begin{array}{l}0.50 \\
0.50\end{array}$ & $\begin{array}{l}0.32 \\
0.52\end{array}$ & $\begin{array}{l}0.19 \\
0.75\end{array}$ & $\begin{array}{r}-0.26 \\
0.62\end{array}$ & 0.009 & $<0.001$ & $<0.001$ & 0.367 & $<0.001$ & 0.073 \\
\hline $\begin{array}{l}\text { Degradation rate of citric acid, } \\
\mathrm{g} / 100 \mathrm{~g}\end{array}$ & $\begin{array}{l}\text { Malic acid } \\
\text { Citric acid }\end{array}$ & $\begin{array}{l}61.0 \\
61.0\end{array}$ & $\begin{array}{l}42.6 \\
52.5\end{array}$ & $\begin{array}{l}24.5 \\
38.6\end{array}$ & $\begin{array}{r}-34.4 \\
21.9\end{array}$ & 1.177 & $<0.001$ & $<0.001$ & $<0.001$ & $<0.001$ & 0.953 \\
\hline
\end{tabular}

${ }^{1}$ Organic acid-treated alfalfa silages.

${ }^{2}$ Total amounts of each acid added at ensiling under application rates of $0.1,0.5$, and $1 \%$ were $0.19,0.97$, and $1.97 \mathrm{~g}$, respectively.

${ }^{3} \mathrm{~A}=$ acid type; $\mathrm{AR}-\mathrm{L}=$ linear effect of application rate; $\mathrm{AR}-\mathrm{Q}=$ quadratic effect of application rate; AR-L $\times \mathrm{A}=$ interaction of linear application rate effect with acid type; $\mathrm{AR}-\mathrm{Q} \times \mathrm{A}=$ interaction of quadratic application rate effect with acid type.

${ }^{4}$ The amount of malic acid degraded was calculated as total amount of malic acid in alfalfa silos at ensiling minus the total residue amount of malic acid in alfalfa silos after ensiling.

${ }^{5}$ The calculation was the same as that of malic acid.

value of acid-treated alfalfa at ensiling. When adding malic acid and citric acid at the level of $1 \%$ of $\mathrm{FW}$, the $\mathrm{pH}$ values of alfalfa at ensiling were 4.95 and 4.79 , respectively; however, at the application levels of 0.1 or $0.5 \%$ of $\mathrm{FW}$, the $\mathrm{pH}$ values of alfalfa at ensiling ranged from 5.21 to 6.03 .

Compared with the untreated silages, application of malic or citric acids at a low level of $0.1 \%$ of $\mathrm{FW}$ decreased the number of yeasts in ensiled alfalfa. Interestingly, yeast growth was promoted after the 2 acids were applied at higher levels of 0.5 and $1 \%$ of FW. Moreover, our results showed that citric acid was more effective than malic acid in promoting the growth of yeast in ensiled alfalfa when their application rates were over $0.5 \%$ of FW. The results of previous studies suggest that malic acid or citric acid can be used by some yeast strains as a carbon and energy source (Zhao et al., 2004; Seo et al., 2007). Therefore, the growth of yeasts might be more competitive than LAB when higher levels of malic or citric acids are applied to ensiled alfalfa. Adding malic or citric acids at ensiling decreased the number of molds in alfalfa silage after $60 \mathrm{~d}$ of fermentation, but application levels of malic or citric acid did not affect the number of molds in ensiled alfalfa.

Because including malic or citric acids provided additional substrates to the silage fermentation, the DM and WSC content in ensiled alfalfa increased with the increased application of malic or citric acids. Reduction in proteolysis during ensilage is a conventional but prevalent concern of ensiled legume forage because extensive proteolysis in silage, mainly caused by plant proteases (Ding et al., 2013), normally results in a low efficiency of $\mathrm{N}$ utilization by ruminants (Givens and Rulquin, 2004). Lowering $\mathrm{pH}$ value in ensiled forage can effectively inhibit proteolysis because plant enzymes are quickly inactivated with a decrease in $\mathrm{pH}$ (Kung and Bedrosian, 2010). A greater reduction of NPN and $\mathrm{NH}_{3}-\mathrm{N}$ concentrations in silages treated with higher levels of malic or citric acids was mainly attributed to the lower $\mathrm{pH}$ values caused by acid treatment of fresh alfalfa at ensiling and by the fermentation of alfalfa after ensiling. When applying the 2 organic acids at rates of 0.1 or $0.5 \%$, citric acid was more effective than malic acid in reducing AA-N and $\mathrm{NH}_{3}-\mathrm{N}$ in silage, but the opposite was true as the application rate reached $1 \%$.

Additionally, the FA composition in ensiled forages has been of interest. Generally, linoleic acid (C18:2n -6) and $\alpha$-linolenic acid (C18:3n-3) make up a major proportion of the FA composition of fresh and ensiled forage (Clapham et al., 2005; Ding et al., 2013). It was reported that a high intake of PUFA could increase the concentration of PUFA in ruminant products (Wood and Enser, 1997; Kalač and Samková, 2010) and consequently be beneficial to human health (Simopoulos, 2001). Therefore, most of the studies on the FA composition of silages are concerned with losses of C18:2n -6 and C18:3n-3 during ensiling (Alves et al., 2011). In agreement with previous reports (Vanhatalo et al., 2007; Ding et al., 2013), ensiling led to lower total FA compared with fresh forage. In addition, including malic or citric acids at ensiling caused a better preservation of total FA in ensiled alfalfa, especially in citric acid-treated silages. Application of malic or citric acids had a small effect on C18:2n-6 but improved the pro- 
portion of C18:3n-3 in total FA. The increased proportions of C18:3n-3 and PUFA as well as the decreased SFA in silages treated with malic or citric acids might be attributable to inhibition of lipoxygenases by these 2 acids because malic acid and citric acid are well-known antioxidants (Brittain, 2001; Aktac et al., 2003). Moreover, citric acid was more effective in increasing the proportions of C18:3n-3 and PUFA than malic acid. With the increased application rates of citric acid, the proportion of C18:3n-3 in silage increased accordingly, but there was no effect of the increased application rates of malic acid.

Compared with the fresh forage, extensive degradation of malic acid and citric acid were observed after ensiling. Concentrations of malic acid and citric acid decreased from 17.9 and $9.2 \mathrm{~g} / \mathrm{kg}$ of DM in fresh forage to 2.7 and $4.23 \mathrm{~g} / \mathrm{kg}$ of DM in the control silage, respectively. Based on the results of degradation of malic and citric acids during ensiling of alfalfa ( 1.45 vs. 0.63 $\mathrm{g}$ ), it can be concluded that the microbes in ensiled alfalfa preferred to use malic acid as a substrate rather than citric acid. However, the fermentation quality and chemical composition of ensiled alfalfa treated by either malic acid or citric acid were comparable. The observed negative value of citric acid degradation in $1 \%$ of $\mathrm{FW}$ of malic acid-treated silage was probably attributable to conversion of malic acid into citric acid during the fermentation of ensiled alfalfa by microbes, as indicated in the tricarboxylic acid cycle.

Previous studies indicate that a supplement of $50 \mathrm{~g}$ (Sniffen et al., 2006) or $84 \mathrm{~g}$ (Devant et al., 2007) of malic acid/cow per day could increase milk production by approximately $2 \mathrm{~kg} / \mathrm{d}$ when fed to dairy cows with a TMR in which silage composed around $50 \%$ of dietary DM. Martin et al. (1999) also reported that providing steers with $80 \mathrm{~g}$ of malic acid/d effectively led to higher ADG of steers compared with the control group (2.11 vs. $1.86 \mathrm{~kg}$ ). Moreover, supplementation of citric acid at $100 \mathrm{~g} /$ steer per day was proven to increase fiber digestibility by steers (Wang et al., 2009a). Li (2005) reported that supplying dairy cows with $20 \mathrm{~g}$ of citric acid/d could effectively improve daily milk production. Our results showed that applying $0.5 \%$ of $\mathrm{FW}$ of malic or citric acids at ensiling was optimal to improve fermentation quality and FA composition and to effectively inhibit proteolysis in ensiled alfalfa. At this application rate, the residues of malic acid and citric acid in alfalfa silage were 11.1 and $13.6 \mathrm{~g} / \mathrm{kg}$ of DM, respectively. In this case, if a dairy cow consumes $20 \mathrm{~kg}$ of malic acid- or citric acid-treated alfalfa silage/d, the malic or citric acid provided by alfalfa silage would be approximately 80 to $100 \mathrm{~g}$, which meets the reported amounts of these 2 organic acids required to improve animal performance.

\section{CONCLUSIONS}

Including malic or citric acids at low application rates of 0.1 or $0.5 \%$ at the ensiling of alfalfa could effectively improve silage fermentation quality, limit proteolysis, and improve FA composition of the ensiled forage. When the application of both organic acids reached $1 \%$ of $\mathrm{FW}$, fermentation in ensiled forage tended to decrease. The effects of malic acid and citric acid on fermentation quality and reduction of NPN in ensiled forage were comparable, but citric acid was more effective than malic acid in improving FA composition of the ensiled forage. Supplementation with $0.5 \%$ of malic or citric acids at ensiling of forage improves silage fermentation and can provide additional feed additives that have proven to promote animal performance. However, the negative effect of increased amounts of yeast after application of a high dose of either acid should be considered, and considering the costs of these 2 organic acids, citric acid is more acceptable in practice.

\section{ACKNOWLEDGMENTS}

Financial support from the National Natural Science Foundation of China, Beijing (project no. 31672487) and the National Public Welfare Industry (Agriculture) R\&D Program of China, Beijing (project no. 201303061) is gratefully acknowledged.

\section{REFERENCES}

Aktac, T., A. Kaboglu, F. Ertan, F. Ekinci, and G. Huseyinova. 2003. The effects of citric acid (antioxidant) and benzoic acid (antimicrobial agent) on the mouse liver: Biochemical and histopathological study. Biologia 58:343-347.

Alves, S. P., A. R. J. Cabrita, E. Jerónimo, R. J. B. Bessa, and A. J. M. Fonseca. 2011. Effect of ensiling and silage additives on fatty acid composition of ryegrass and corn experimental silages. J. Anim. Sci. 89:2537-2545.

AOAC. 1990. Official Methods of Analysis. 15th ed. Association of Official Analytical Chemists, Arlington, VA.

Branen, A. L., and T. W. Keenan. 1970. Growth stimulation of Lactobacillus casei by sodium citrate. J. Dairy Sci. 53:593-597.

Brittain, H. G. 2001. Malic acid. Analytical Profiles Drug Substances Excipients 28:153-195.

Broderick, G. A., and J. H. Kang. 1980. Automated simultaneous determination of ammonia and total amino acid in ruminal fluid and in vitro media. J. Dairy Sci. 63:64-75.

Callaway, T. R., S. A. Martin, J. L. Wampler, N. S. Hill, and G. M. Hill. 1997. Malate content of forage varieties commonly fed to cattle. J. Dairy Sci. 80:1651-1655.

Carro, M. D., S. López, C. Valdès, and F. J. Ovejero. 1999. Effect of DL-malate on mixed ruminal microorganism fermentation using the rumen simulation technique (RUSITEC). Anim. Feed Sci. Technol. 79:279-288.

Carro, M. D., and M. J. Ranilla. 2003. Effect of the addition of malate on in vitro rumen fermentation of cereal grains. Br. J. Nutr. 89:181-188.

Castillo, C., J. L. Benedito, J. Mendez, V. Pereira, M. Lopez-Alonso, M. Miranda, and J. Hernandez. 2004. Organic acids as a substitute for monensin in diets for beef cattle. Anim. Feed Sci. Technol. 115:101-116. 
Castillo, C., J. L. Benedito, V. Pereira, P. Vázquez, A. M. López, and J. Méndez. 2007. Malic acid supplementation in growing/finishing feedlot bull calves: Influence of chemical form on blood acid-base balance and productive performance. Anim. Feed Sci. Technol. 135:222-235

Clapham, W. M., G. F. Joyce, P. S. N. James, and M. F. James. 2005. Fatty acid composition of traditional and novel forages. J. Agric. Food Chem. 53:10068-10073.

Devant, M., A. Bach, and J. A. Garcia. 2007. Effect of malate supplementation to dairy cows on rumen fermentation and milk production in early lactation. J. Appl. Anim. Res. 31:169-172.

Ding, W. R., R. J. Long, and X. S. Guo. 2013. Effects of plant enzyme inactivation or sterilization on lipolysis and proteolysis in alfalfa silage. J. Dairy Sci. 96:2536-2543.

Givens, D. I., and H. Rulquin. 2004. Utilization by ruminants of nitrogen compounds in silage-based diets. Anim. Feed Sci. Technol. $114: 1-18$

Hoedtke, S., and A. Zeyner. 2011. Comparative evaluation of laboratory-scale silages using standard glass jar silages or vacuum-packed model silages. J. Sci. Food Agric. 91:841-849.

Johnson, H. E., R. J. Merry, D. R. Davies, D. B. Kell, M. K. Theodorou, and G. W. Griffith. 2005. Vacuum packing: A model system for laboratory-scale silage fermentations. J. Appl. Microbiol. 98:106-113.

Kalač, P., and E. Samková. 2010. The effect of feeding various forages on fatty acid composition of bovine milk fat: A review. Czech J. Anim. Sci. 55:521-537.

Kung, L., Jr., and M. D. Bedrosian. 2010. How well do we really understand silage fermentation? Pages 87-93 in Proceedings of the Cornell Nutrition Conference for Feed Manufacturers. Cornell University, Ithaca, NY.

Li, P., S. Ji, C. Hou, H. Tang, Q. Wang, and Y. Shen. 2016. Effects of chemical additives on the fermentation quality and $\mathrm{N}$ distribution of alfalfa silage in south of China. Anim. Sci. J. 87:1472-1479.

Li, Z. Q. 2005. The effect of the interaction of organic acid and honey material on the productivity of dairy cow. MS Thesis. Jilin Agricultural University, Jilin, China.

Licitra, G., T. M. Hernandez, and P. J. Van Soest. 1996. Standardization of procedures for nitrogen fractionation of ruminant feeds. Anim. Feed Sci. Technol. 57:347-358.

Martin, S. A., and M. N. Streeter. 1995. Effect of malate on in vitro mixed ruminal microorganism fermentation. J. Anim. Sci $73: 2141-2145$.

Martin, S. A., M. N. Streeter, D. J. Nisbet, G. M. Hill, and S. E. Williams. 1999. Effects of DL-malate on ruminal metabolism and performance of cattle fed a high-concentrate diet. J. Anim. Sci. $77: 1008-1015$

Mills, J. A., and L. Kung. 2002. The effect of delayed ensiling and application of a propionic acid-based additive on the fermentation of barley silage. J. Dairy Sci. 85:1969-1975.

Owens, V. N., K. A. Albrecht, R. E. Muck, and S. H. Duke. 1999. Protein degradation and fermentation characteristics of red clover and alfalfa silage harvested with varying levels of total nonstructural carbohydrates. Crop Sci. 39:1873-1880.

Packett, L. V., and G. A. Butcher. 1963. Effects of dietary sodium citrate and oxytetracycline upon fattening lambs. J. Anim. Sci. 22:1100-1103.
Passos, F. V., H. P. Fleming, H. M. Hassan, and R. F. McFeeters. 2003. Effect of malic acid on the growth kinetics of Lactobacillus plantarum. Appl. Microbiol. Biotechnol. 63:207-211.

Reich, L. J., and L. Kung. 2010. Effects of combining Lactobacillus buchneri 40788 with various lactic acid bacteria on the fermentation and aerobic stability of corn silage. Anim. Feed Sci. Technol. 159:105-109.

Salou, P., M. J. Leroy, G. Goma, and A. Pareilleux. 1991. Influence of $\mathrm{pH}$ and malate-glucose ratio on the growth of Leuconostoc oenos. Appl. Microbiol. Biotechnol. 36:87-91.

Seo, S. H. C. H. Rhee, and H. D. Park. 2007. Degradation of malic acid by Issatchenkia orientalis KMBL 5774 , an acidophilic yeast strain isolated from Korean grape wine pomace. J. Microbiol. 45:521-527.

Simopoulos, A. P. 2001. n-3 fatty acids and human health: Defining strategies for public policy. Lipids 36:S83-S89.

Sniffen, C. J., C. S. Ballard, M. P. Carter, K. W. Cotanch, H. M. Danna, R. J. Grant, P. Mandebvu, M. Suekawa, and S. A. Martin. 2006. Effects of malic acid on microbial efficiency and metabolism in continuous culture of rumen contents and on performance of mid-lactation dairy cows. Anim. Feed Sci. Technol. 127:13-31.

Sukhija, P. S., and D. L. Palmquist. 1988. Rapid method for determination of total fatty acid content and composition of feedstuffs and feces. J. Agric. Food Chem. 36:1202-1206.

Sun, W., M. Mitsumori, and A. Takenaka. 2008. The detection of possible sensor histidine kinases regulating citrate/malate metabolism from the bovine rumen microbial ecosystem. Lett. Appl. Microbiol. $47: 462-466$.

Thomas, T. A. 1977. An automated procedure for the determination of soluble carbohydrates in herbage. J. Sci. Food Agric. 28:639-642.

Tyrolova, Y., and A. Vyborna. 2008. Effect of the stage of maturity on the leaf percentage of lucerne and the effect of additives on silage characteristics. Czech J. Anim. Sci. 53:330-335.

Van Soest, P. J., J. B. Robertson, and B. A. Lewis. 1991. Methods for dietary fiber, neutral detergent fiber, and nonstarch polysaccharides in relation to animal nutrition. J. Dairy Sci. 74:3583-3597.

Vanhatalo, A., K. Kuoppala, V. Toivonen, and K. J. Shingfield. 2007. Effects of forage species and stage of maturity on bovine milk fatty acid composition. Eur. J. Lipid Sci. Technol. 109:856-867.

Wang, C., Q. Liu, J. Meng, W. Z. Yang, X. M. Yang, D. C. He, K. H Dong, and Y. X. He. 2009a. Effects of citric acid supplementation on rumen fermentation, urinary excretion of purine derivatives and feed digestibility in steers. J. Sci. Food Agric. 121:15-20.

Wang, C., Q. Liu, W. Z. Yang, Q. Dong, X. M. Yang, D. C. He, K. H. Dong, and Y. X. Huang. 2009b. Effects of malic acid on feed intake, milk yield, milk components and metabolites in early lactation Holstein dairy cows. Livest. Sci. 124:182-188.

Wood, J. D., and M. Enser. 1997. Factors influencing fatty acids in meat and the role of antioxidants in improving meat quality. Br. J. Nutr. 78(Suppl. 1):S49-S60.

Zhao, Y. P., L. X. Du, L. L. Liu, and E. Y. Wang. 2004. Screening yeast degrading citric acid in Hawthorn fruit juice and its degrading characteristics. Acta Microbiol. Sin. 44:235-239. 